\title{
POTENT BIOACTIVE METABOLITES OF CASUARINA JUNGHUHNIANA MIQ. ROOTS-A THERAPEUTIC APPROACH
}

\author{
CHATHURDEVI G. ${ }^{*}$, S. UMAGOWRIE ${ }^{* *}$ \\ Department of Plant Biology and Plant Biotechnology, Ethiraj College for Women, Chennai 600008, Tamil Nadu, India \\ Email: umasezhian@gmail.com
}

Received: 21 Nov 2016 Revised and Accepted: 17 Jan 2017

\section{ABSTRACT}

Objective: Casuarina junghuhniana Miq. is a multipurpose tree, belongs to the family Casuarinaceae. It has a symbiotic association with actinomycete Frankia which makes the tree to grow vigorously on varied environmental conditions. Not much work has been documented on secondary metabolites and therapeutic approach of this species in India. Therefore, the objective of the present study was to explore the potential phytochemicals in the root extracts and its therapeutic values.

Methods: Casuarina junghuhniana root samples were collected from the State Forest Research Institute, Kolappakam, Chennai. The qualitative and quantitative phytochemicals screening were carried out using standard procedures. Antibacterial assay was tested against different pathogens using well diffusion method. Antioxidant activity was carried out using reducing power, hydrogen peroxide scavenging and 1, 1-diphenyl-2picrylhydrazyl (DPPH) free radical scavenging methods. The anti-inflammatory assay was tested using protein denaturation method. Further, the phytochemicals in the root extract were evaluated using GC-MS studies. The functional role of the phytoconstituent was confirmed by docking against the target using mcule software.

Results: The qualitative screening revealed the presence of various phytoconstituents. The quantitative analysis revealed the presence of maximum phenols $(68.95 \pm 0.46 \mathrm{mg} / \mathrm{g})$, flavonoids $(34.15 \pm 0.33 \mathrm{mg} / \mathrm{g})$ and terpenoids $(3.9 \%)$ in methanolic root extract with respective standards. Antibacterial activity showed a maximum zone of inhibition against Bacillus subtilis (19 $\pm 0.2 \mathrm{~mm})$ followed by Staphylococcus sp (14 \pm 0.3 mm). The antioxidant and anti-inflammatory activity was compared with standard ascorbic acid and the extract showed activities in a dose-dependent manner. Several peaks were obtained in the GC-MS analysis which indicates the presence of different secondary metabolites. The specific phytocompound showed prominent binding affinity against the target enzyme in docking studies.

Conclusion: The presence of potent phytochemicals in the Casuarina junghuhniana root with antioxidant and anti-inflammatory activities could be used as a promising source for developing novel plant-based therapeutic agents.

Keywords: $C$. junghuhniana, Root, Phytochemicals, Antioxidant, GC-MS, In silico

(C) 2016 The Authors. Published by Innovare Academic Sciences Pvt Ltd. This is an open access article under the CC BY license (http://creativecommons.org/licenses/by/4. 0/] DOI: http://dx.doi.org/10.22159/ijpps.2017v9i3.16264

\section{INTRODUCTION}

Plants are the rich source of bioactive secondary metabolites that has been used as a potential source of many therapeutic agents in the treatment of a wide spectrum of human ailments. The Plant based therapeutic agents have scientific, social and commercial significance. The medicinal property of the plant lies in the bioactive compound synthesised in their secondary metabolism. The most important secondary metabolites include phenols, flavonoids, tannins, alkaloids, steroids, etc.,[1] There is a continuous and urgent need to discover new plant-based therapeutic compounds with the diverse chemical structure for new and re-emerging infectious diseases [2].

Casuarina junghuhniana Miq. is one of the most important members of nitrogen fixing, woody, a non-leguminous tree belonging to family Casuarinaceae. It has a symbiotic association with actinomycete Frankia which makes the tree to grow vigorously on varied soil types and in extreme environmental conditions.

C. junghuhniana is an exotic species originated in Indonesia. In India, within two decades of its systematic introduction in 1996, C. junghuhniana proved to be more preferred species than widely cultivated $C$. equisetifolia [3]. In recent years, $C$. junghuhniana has gained popularity among farmers in South India due to its various desirable characters such as growth rate, cultivation practices and marketability [4]. It is a fast growing, drought resistant with the good coppicing ability and has not affected by blister bark diseasehost specific as well as free from pests and pathogens. The tree has various end uses such as pulpwood, fuel wood, and poles in India. It is also widely used for sand dune stabilisation, shelterbelts, and windbreak in agroforestry systems.
However, the emphasis is being laid over on the improvement of yield and quality of species; not much work has been documented on secondary metabolites and therapeutic approach of this species in India.

Casuarina junghuhniana tree has recorded faster growth which is widely grown in Tamil Nadu with 3 to $4 \mathrm{y}$ of crop rotation period and hence is a desirable tree crop to the farmers in the field of agroforestry. Since the plant root and bark are the waste materials during pulping in the paper industry, the plant root has been taken for the present study to evaluate the potential phytoconstituents and its therapeutic values.

Therefore the objective of the present work was to screen the qualitative and quantitative phytochemicals, antimicrobial, antioxidant and anti-inflammatory potential of root using different solvents. The GC-MS analysis was carried out to characterize the presence of bioactive compounds in the root extract. The functional role of selected potent phytochemical was further studied using in silico work.

\section{MATERIALS AND METHODS}

\section{Collection of plant material}

The plus trees of Casuarina junghuhniana were identified from State Forest Research Institute, Kolapakkam which is located at latitude $\left(12{ }^{\circ} 8713 \mathrm{~N}\right)$ and longitude $\left(80^{\circ} 1018 \mathrm{E}\right)$ of Chennai City, Tamil $\mathrm{Nadu}$, India. Healthy root samples were collected from $4 \mathrm{y}$ old plantation site. Identification (authentication) of the plant sample was confirmed at Botanical Survey of India (BSI), Coimbatore, Tamil Nadu. (BSI/SRC/5/23/2015/Tech/2153). 


\section{Preparation of plant extracts}

The collected roots were thoroughly washed, shade dried and finely powdered. Powdered root materials were extracted with different solvents such as Acetone, Chloroform, Ethanol, Methanol and Aqueous using cold percolation method. The extracts were then concentrated and dried under reduced pressure and preserved at 5 ${ }^{\circ} \mathrm{C}$ until further use.

\section{Qualitative phytochemical screening}

The different root extracts (Acetone (RA), Chloroform (RC), Ethanol (RE), Methanol (RM) and Aqueous extracts (RW)) were checked for the presence of secondary metabolites such as alkaloids, phenols, tannins, flavonoids, terpenoids, proteins and amino acids, carbohydrates, steroids, phlobatanin saponin, Gum and mucilage using standard procedures $[5,6]$.

\section{Quantitative estimation}

\section{Estimation of total phenol content}

Total phenolic content of ethanol, methanol and aqueous extract of C. junghuhniana root was determined by Folin-ciocalteu reagent method with modification. To the crude extract $(1 \mathrm{mg}), 5 \mathrm{ml}$ distilled water and $0.5 \mathrm{ml}$ Folin-ciocalteu reagent was added and incubated for $5 \mathrm{~min}$. Later $20 \% \mathrm{Na} 2 \mathrm{CO} 3(1.5 \mathrm{ml})$ was added to the solution and volume was made up to $10 \mathrm{ml}$ with distilled water. Finally, the test solutions were kept in the dark for $2 \mathrm{~h}$. After incubation, the absorbance of blue color was read at $750 \mathrm{~nm}$ using UV Spectrophotometer (UV 1650PC Shimadzu). Total phenolic content was calculated as Gallic acid equivalents (mg of GAE/g of extract) [7].

\section{Estimation of total flavonoid content}

Total flavonoids content of ethanol, methanol and aqueous extract of C. junghuhniana root was determined by aluminium chloride colorimetric assay. To $1 \mathrm{ml}$ of the test sample, $4 \mathrm{ml}$ of distilled water and $0.3 \mathrm{ml}$ of $5 \%$ sodium nitrite solution was added and incubated for $5 \mathrm{~min}$. After incubation, $0.3 \mathrm{ml}$ of $10 \%$ aluminium chloride and 2 $\mathrm{ml}$ of $1 \mathrm{M}$ sodium hydroxide was added. Finally, the volume was made up to $10 \mathrm{ml}$ with distilled water. Orange yellowish colour was developed. The absorbance was measured at $510 \mathrm{~nm}$ using UV Spectrophotometer (UV 1650PC Shimadzu). Total flavonoids content was calculated as Quercetin equivalents (mg of QAE/g of extract) [7].

\section{Estimation of total terpenoids}

Total terpenoid content of ethanol, methanol and aqueous extract of C. junghuhniana root was determined by Ferguson's method. The crude extract was soaked in $20 \mathrm{ml}$ alcohol (95\% ethanol) for $24 \mathrm{~h}$. The filtrate was extracted with petroleum ether $\left(60^{\circ} \mathrm{C}-80{ }^{\circ} \mathrm{C}\right)$ and the ether extract was treated as total terpenoids. The residue obtained was dried and weighed [8].

$$
\text { Terpenoid content }(\%)=\frac{\text { Weight of terpenoid extract }(\mathrm{g})}{\text { Weight of the sample }(\mathrm{g})} \times 100
$$

\section{Antibacterial activity}

The different root extracts (ethanol, methanol and aqueous extracts) of $50 \mu \mathrm{g}$ and $100 \mu \mathrm{g}$ were assayed for its antibacterial activity by well diffusion method using Muller Hinton Media. The extracts were tested against Bacillus subtilis, Escherichia coli, Proteus vulgaris, Pseudomonas aeruginosa, and Staphylococcus aureus. Gentamycin $(100 \mu \mathrm{g})$ was used as positive control. The plates were incubated at $37^{\circ} \mathrm{C}$. Zone of inhibition around the well was observed after $24 \mathrm{~h}$ for antibacterial assay. Triplicates were maintained.

\section{Antioxidant activity}

\section{Hydrogen peroxide scavenging assay}

The ability of root extracts to scavenge hydrogen peroxide was determined according to the method of Ruch et al. 1989 [9]. The extracts of $0.1 \mathrm{ml}$ of different concentrations $(100,200,300,400$, $500 \mu \mathrm{g}$ ), were dissolved in $3.4 \mathrm{ml}$ of $0.1 \mathrm{M}$ phosphate buffer (pH-7.4) and mixed well with $0.6 \mathrm{ml}$ of $43 \mathrm{mmol}$ hydrogen peroxide solution. The absorbance of the reaction mixture was read at $230 \mathrm{~nm}$ using a
UV Spectrophotometer. Ascorbic acid was used as a standard. The hydrogen peroxide scavenging activity was calculated using the formula:

Hydrogen peroxide scavenging effect $(\%)=\mathrm{Ac}-\mathrm{Ao} / \mathrm{Ac} \times 100$

Where $A_{c}$ is the absorbance of control, $A_{o}$ is the absorbance of sample

\section{Reducing power assay}

The reducing power assay of the root extracts was analyzed using standard method [10]. To different concentrations of the samples $(100,200,300,400,500 \mu \mathrm{g}), 2.5 \mathrm{ml}$ of phosphate buffer (pH-6.6)and $2.5 \mathrm{ml}$ of $1 \%$ potassium ferricyanide solution was added and mixed well. This mixture was kept at $50^{\circ} \mathrm{C}$ in a water bath for $20 \mathrm{~min}$. After cooling the test tubes, $2.5 \mathrm{ml}$ of $10 \%$ trichloroacetic acid was added and centrifuged at $3000 \mathrm{rpm}$ for $10 \mathrm{~min} .2 .5 \mathrm{ml}$ of the supernatant was mixed with $2.5 \mathrm{ml}$ of distilled water and $0.5 \mathrm{ml}$ of $0.1 \%$ ferric chloride solution and the mixture was kept undisturbed for $10 \mathrm{~min}$. The absorbance of the resulting solution was measured at $700 \mathrm{~nm}$ using UV Spectrophotometer. The increase in absorbance of the reaction mixture indicates increased reducing power. Ascorbic acid was used as a standard. The reducing power assay was calculated using the formula.

$$
\text { Reducing power assay }(\%)=\frac{\text { Control OD }- \text { Test OD }}{\text { Control OD }} \times 100
$$

\section{DPPH radical scavenging assay}

Free radical scavenging activity of the root extracts was measured by 1, 1-diphenyl-2-picrylhydrazyl (DPPH). $0.1 \mathrm{mmol}$ solution of DPPH in methanol was prepared. $1 \mathrm{ml}$ of DPPH was added to $3 \mathrm{ml}$ of different concentrations of the sample $(100,200,300,400,500 \mu \mathrm{g})$. The above mixture was shaken vigorously and allowed to stand at room temperature for $30 \mathrm{~min}$. The absorbance was measured at 517 $\mathrm{nm}$ in UV Spectrophotometer. The experiment was carried out using ascorbic acid as standard. The DPPH scavenging effect was calculated using the following equation:

$$
\begin{gathered}
\text { DPPH scavenging effect }(\%) \text { or Percent inhibtion } \\
=\mathrm{A} 0-\mathrm{A} 1 / \mathrm{A} 0 \times 100
\end{gathered}
$$

Where $A_{0}$ is the absorbance of control, and $A_{1}$ is the absorbance of the test sample [10].

All the above assays were performed in triplicates.

\section{In vitro anti-inflammatory assay (Inhibition of the albumin denaturation)}

To $100 \mu \mathrm{l}$ of different concentrations $(100,200,300,400,500 \mu \mathrm{g})$ sample, $500 \mu \mathrm{l}(1 \%)$ Bovine Serum Albumin was added. The sample extracts were incubated at $37^{\circ} \mathrm{C}$ for $10 \mathrm{~min}$ and then heated to $51^{\circ} \mathrm{C}$ for $20 \mathrm{~min}$. After cooling the samples, the turbidity was measured using a UV Spectrophotometer at $660 \mathrm{~nm}$. Diclofenac sodium was used as a standard drug. The experiment was performed in triplicates [10]. Percent inhibition of protein denaturation was calculated using the formula.

$$
\% \text { Inhibition }=\frac{\text { Control OD }- \text { Test OD }}{\text { Control OD }} \times 100
$$

\section{GC MS studies}

The methanol root extract (extracted using HPLC grade Methanol) was subjected to GC MS analysis to identify the bioactive compounds. GC-MS analysis was performed at the SAIF, IIT-Madras, Chennai, Tamil Nadu. The sample was subjected to GC and MS JEOL GC mate equipped with a secondary electron multiplier. JEOL GCMATE II GC-MS (Agilent Technologies 6890N Network GC system for gas chromatography). The column (HP5) was fused silica $50 \mathrm{~m} \mathrm{X}$ $0.25 \mathrm{~mm}$ I.D. The experimental conditions were $20 \mathrm{~min}$ at $100^{\circ} \mathrm{C}$, column temperature: $235^{\circ} \mathrm{C}$ for $3 \mathrm{~min}$; injector temperature: $240^{\circ} \mathrm{C}$; carrier gas: helium; and split ratio: $5: 4$. $1 \mu \mathrm{l}$ of the sample was evaporated in a splitless injector at $300^{\circ} \mathrm{C}$ and the run time was 40 min. The active phytochemical components were identified by gas chromatography coupled with mass spectrometry. The spectrum of GC-MS was analyzed using the database of National Institute Standard and Technology (NIST) having more than 62,000 patterns. 


\section{In silico analysis (Docking studies)}

In silico analysis through molecular docking plays a significant role in studying the functional role of the specific bioactive compound. The compounds identified by GC-MS analysis in the Casuarina junghuhniana were screened against the target protein (sortase) in order to study the anti-microbial property. The target molecule was retrieved from (PDB) Protein Data Bank (http://www. rcsb. org/pdb/). The bioactive compound details were retrieved from the Pubchem database. The bioactive compounds were docked against the target protein using bioinformatics tools. Docking results in interactions between the target and ligand molecules. Docking studies were carried out to confirm the anti-microbial property of the phyto compound. Streptomycin was used as a standard anti-microbial compound.

\section{Statistical analysis}

For each experiment, data presented are the means of three replicates. Values are expressed as mean \pm SD of three replicates.

\section{RESULTS AND DISCUSSION}

Casuarina junghuhniana roots were collected from State Forest Research Institute, Kolapakkam. The roots were dried and powdered. (fig. 1a and 1b).

\section{Qualitative phytochemical screening}

The results of preliminary qualitative phytochemical screening of different extracts of root of Casuarina junghuhniana showed the presence of varied phytochemicals. (table 1). The ethanol, methanol and aqueous extract of the root alone showed the presence of phenol, flavonoids, tannin and terpenoids. Aqueous root extract alone showed the presence of alkaloids and glycosides. Except for chloroform root extract, all other root extracts showed the presence of carbohydrates and proteins.

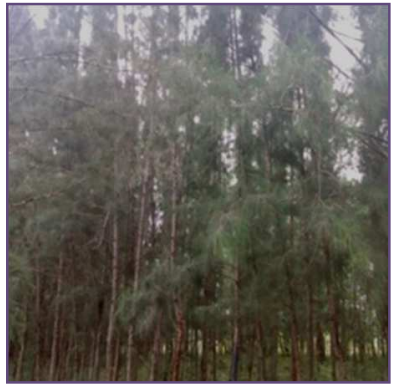

Fig. 1a: Casuarina junghuhniana plantation

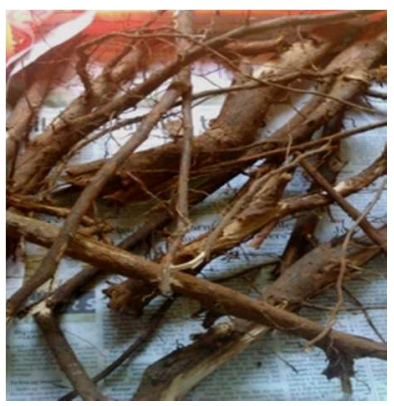

Fig. 1b: Casuarina junghuhniana root

Table 1: Phytochemical Analysis of different extracts of root of $C$. junghuhniana

\begin{tabular}{|c|c|c|c|c|c|c|}
\hline S. No. & Phytochemical test & RA & RC & $\mathbf{R E}$ & $\mathbf{R M}$ & RW \\
\hline 1 & Alkaloid & - & - & - & - & + \\
\hline 2 & Glycoside & - & - & - & - & + \\
\hline 3 & Carbohydrate & + & - & + & + & + \\
\hline 4 & Proteins & + & - & + & + & + \\
\hline 5 & Phenol & - & - & + & + & + \\
\hline 6 & Flavonoid & - & - & + & + & + \\
\hline 7 & Tannin & - & - & + & + & + \\
\hline 8 & Terpenoid & - & - & + & + & + \\
\hline
\end{tabular}

+: Presence.-: Absence, RA-Acetone root extract, RC-Chloroform root extract, RE-Ethanol root extract, RM-Methanol root extract, RW-Aqueous root extract of Casuarina junghuhniana.

The observations from the present study can be rationalized in terms of the polarity of the compounds being extracted by each solvent. The presence of phytochemicals such as alkaloids, flavonoids, phenols, tannins and Terpenoids from the root of related Casuarina species (Casuarina equisetifolia) has been reported [11]. The chemical constituents in the plants or in crude extracts are known to be biologically active metabolites. Some chemical constituents are considered as secondary metabolites [12]. The primary function of phytochemical is to protect the plants from pathogens that bring damage to the plant. Besides that, it is also a source of colour, aroma and flavor for specific parts of the plant. Moreover, phytochemicals are also useful in plant protection over environmental hazards such as pollution, UV exposure and stress drought [13]. The secondary metabolites in plants are directly responsible for various activities such as antimicrobial, antioxidant and anti-cancer activities [14]. The presence of phytochemicals within root can be a potential source for medicinal use and it is also an indicator that they can be a promising source for developing novel plant-based therapeutic agents.

Since, ethanol, methanol and aqueous root extracts alone revealed positive results in qualitative phytochemical analysis, further work was carried out only with these three root extracts.

\section{Quantitative phytochemical analysis}

The total phenolic content in 3 different extracts of Casuarina junghuhniana root determined by Folin-ciocalteu method was reported as Gallic acid equivalent (Standard Curve equation $\left.\mathrm{Y}=0.027 \mathrm{x}+0.176, \mathrm{R}^{2}=0.994\right)$. Among the three extracts, methanol extract contained maximum phenol content $(68.5 \pm 0.2 \mathrm{mg} / \mathrm{g})$, followed by ethanol extract $(63.4 \pm 0.3 \mathrm{mg} / \mathrm{g})$ and aqueous extract $(43.5 \pm 0.3 \mathrm{mg} / \mathrm{g})$. (fig. 2 )

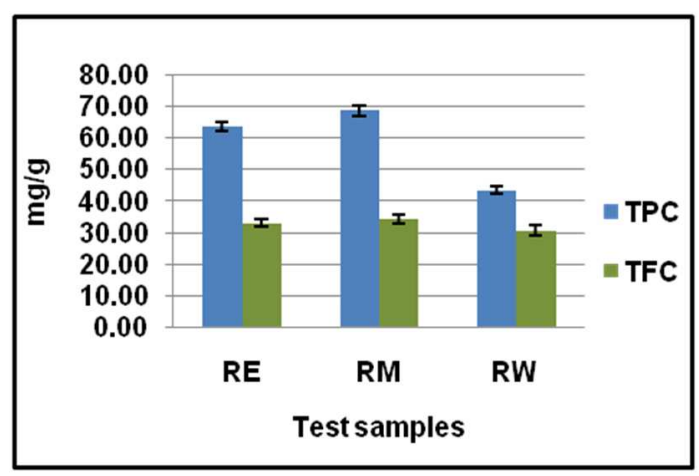

Fig. 2: Total phenol content (TPC) and total flavonoids content (TFC) in Casuarina junghuhniana root. Data presented are the means of three replicates. Values are expressed as mean \pm SD of three replicates 
The total flavonoid content in 3 different extracts of Casuarina junghuhniana root determined by aluminium chloride colorimetric method was reported as Quercetin equivalent (Standard Curve equation $\left.\mathrm{Y}=0.009 \mathrm{x}+0.136, \mathrm{R}^{2}=0.997\right)$. Among the three extracts, methanol extract contained maximum flavonoids content $(34.3 \pm 0.4$ $\mathrm{mg} / \mathrm{g})$, followed by ethanol extract $(32.9 \pm 0.2 \mathrm{mg} / \mathrm{g})$ and aqueous extract ( $30.5 \pm 0.3 \mathrm{mg} / \mathrm{g}$ ). (fig. 2)

The methanol root extracts showed maximum terpenoid content (3.9\%) followed by ethanol extract (3\%) and aqueous extract (2.5\%) (fig. 3)

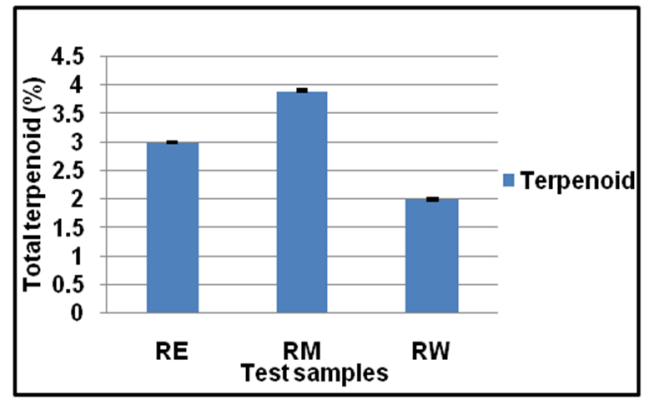

Fig. 3: Total Terpenoid content in Casuarina junghuhniana root. Data presented are the means of three replicates. Values are expressed as mean \pm SD of three replicates

In the present study, the quantitative analysis revealed that methanol root extract has maximum phenols, flavonoids and terpenoids. The biological activity of plant matter are greatly influenced by the nature of the extracting solvent owing to the presence of different bioactive compounds of different chemical properties and polarities that may or may not be soluble in a particular solvent [15]. Determination of total phenolic content of aqueous extract of root bark of Casuarina littorea was found to be $6.68 \pm .03 \mathrm{mg} / \mathrm{g} \mathrm{GAE}[16]$.

Phenolic compounds are broadly distributed in the plant kingdom and are most abundant secondary metabolites of the plant. They are generally involved in defence against UV radiations, aggression by pest and pathogens and also contribute to plant colour [17]. These phenolics compounds are a class of antioxidant agents which act as free radical terminators [18] and exhibit strong antioxidant properties due to their redox potential, which allow them to act as reducing agents, hydrogen donators, metal chelators and singlet oxygen quencher [19].

Flavonoids are one of the most diverse and largest classes of plant phenolics performing various functions in plant system including pigmentation and defence [20]. Several flavonoids have been reported to quench active oxygen species and inhibit in vitro oxidation of low-density lipoproteins [21, 22]. Flavonoids have been reported to possess various properties such as antimicrobial, antioxidant, anti-inflammatory, ostrogenic, enzyme inhibition, antiallergic, vascular and cytotoxic antitumor activities [23]. The antioxidant properties of flavonoids are due to the presence of a number of phenolic hydroxyl groups attached to ring structures [24].

Terpenoids are also known as isoprenoids, constituting the largest class of natural products. They are widely used in the field of medicine and in industrial sectors as flavors, fragrance, spice, in the preparation of perfumes and cosmetics [25]. Terpenes react with free radicals by partitioning themselves into fatty membranes by virtue of their long carbon side chain and thus exhibiting unique antioxidant activity [26].

\section{Anti-bacterial activity}

The results indicated that the root extracts showed antibacterial activities at variable degrees against different bacterial pathogens. The methanol extracts of root showed remarkable antibacterial activity compared to ethanol and aqueous extracts against the test pathogens. The maximum zone of inhibition was seen at $100 \mu \mathrm{g}$ concentration against Bacillus subtilis $(19 \pm 0.2 \mathrm{~mm})$, followed by Staphylococcus aureus ( $14 \pm 0.2 \mathrm{~mm}$ ). (fig. 4). Ethanol root extract and aqueous root extract showed a maximum zone of inhibition against Staphylococcus aureus with $11 \pm 0.3 \mathrm{~mm}$ and $10 \pm 0.4 \mathrm{~mm}$ respectively. The control gentamycin at $100 \mu \mathrm{g}$ concentration showed $(21 \pm 0.7$ $\mathrm{mm}$ ) against the tested bacterial pathogens.

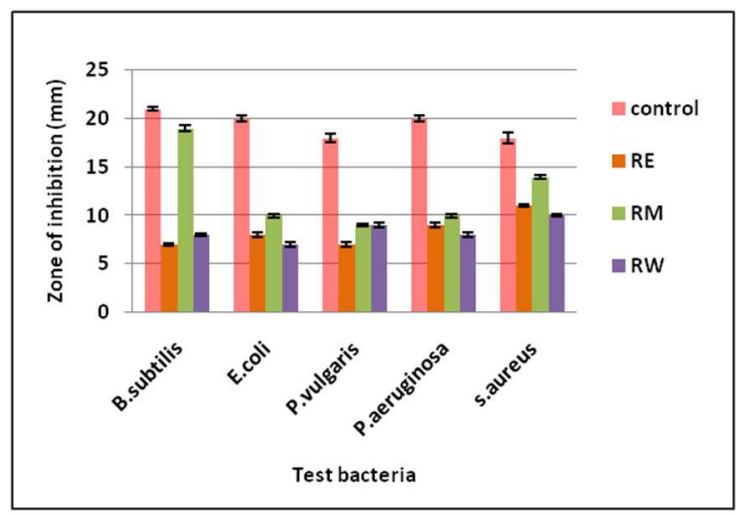

Fig. 4: Antibacterial activity of Casuarina junghuhniana root extract against different bacterial pathogens at $100 \mu \mathrm{g}$ concentration. Data presented are the means of three replicates. Values are expressed as mean \pm SD of three replicates

In this study, Methanol extracts of root had a higher solubility for more phytoconstituents resulting the highest antibacterial activity. The presence of phytochemicals such as higher phenol and flavonoids in root extract may be responsible for the antimicrobial activity. There is an increasing rate of resistance to existing antibiotics, and this problem extends beyond the clinical application of antimicrobial drugs. Plant-based antimicrobials have wide therapeutic potentials as they serve with lesser side effects [27]. Flavonoids are grouped under phenolics, and it acts as an antimicrobial agent by inhibiting the nucleic acid synthesis, cytoplasmic membrane function and energy metabolism [28].

\section{Anti-oxidant activity}

The antioxidant assay was carried out at different concentrations $(100,200,300,400,500 \mu \mathrm{g})$ of ethanol, methanol and aqueous extracts of Casuarina junghuhniana root and was compared with standard ascorbic acid. The antioxidant potential of different extracts was determined based on their $\mathrm{IC}_{50}$ value. The $\mathrm{IC}_{50}$ value is the measure of the extract concentration that is required for $50 \%$ inhibition. Lesser $\mathrm{IC}_{50}$ value denotes the higher antioxidant potential of the sample.

\section{Hydrogen peroxide scavenging assay}

$\mathrm{H}_{2} \mathrm{O}_{2}$ inactivate few enzymes directly, usually through oxidation of essential thiol $(-\mathrm{SH})$ groups. $\mathrm{H}_{2} \mathrm{O}_{2}$ react with $\mathrm{Fe}^{2+}$ and possibly $\mathrm{Cu}^{2+}$ ions resulting in the formation of hydroxyl radical which may be the origin of oxidative damage. In the present study, the percent inhibition at various concentrations (100-500 $\mu \mathrm{g})$ was evaluated. The methanol extract showed per cent maximum inhibition at $500 \mu \mathrm{g}$ concentration $(83 \pm 0.6)$ followed by ethanol extract $(79 \pm 0.4)$ and aqueous extract $(74 \pm 0.5)$ with IC 50 value of $165.45 \mu \mathrm{g} / \mathrm{ml}$, $224.56 \mu \mathrm{g} / \mathrm{ml}$ and $247.27 \mu \mathrm{g} / \mathrm{ml}$ respectively. The hydrogen peroxide scavenging activity of standard ascorbic acid showed maximum percent inhibition of $(91 \pm 0.8)$ at $500 \mu \mathrm{g}$ concentration with IC $\mathrm{C}_{50 v a l u e}$ of $105.08 \mu \mathrm{g} / \mathrm{ml}$. (fig. 5)

\section{Reducing power assay}

The reducing power has a significant correlation with the antioxidant activity. The concentration of $\mathrm{Fe}^{2+}$ formed by the reduction of the $\mathrm{Fe}^{3+} /$ ferricyanide complex was monitored by measuring the formation of Prussian blue at $700 \mathrm{~nm}$ [29]. In the present study, the reducing power activity of different extracts of 
Casuarina junghuhniana root was evaluated. The methanol extract showed per cent maximum reducing ability at $500 \mu \mathrm{g}$ concentration $(87 \pm 0.3)$ followed by ethanol extract $(83 \pm 0.2)$ and aqueous extract $(78 \pm 0.3)$ with IC 50 value of $147.86 \mu \mathrm{g} / \mathrm{ml}, 175.67 \mu \mathrm{g} / \mathrm{ml}$ and $236.84 \mu \mathrm{g} / \mathrm{ml}$ respectively. The reducing power activity of standard ascorbic acid showed maximum percent inhibition of $(91 \pm 0.8)$ at $500 \mu \mathrm{g}$ concentration with $\mathrm{IC}_{50}$ value of $105.08 \mu \mathrm{g} / \mathrm{ml}$. (fig. 6)

\section{DPPH radical scavenging assay}

DPPH is a stable free radical at room temperature, purple in colour. The degree of discolouration of DPPH by its reduction indicated the radical scavenging activity. In our present study, DPPH radical scavenging activity was recorded in terms of percent inhibition. The methanol extract showed per cent maximum inhibition at $500 \mu \mathrm{g}$ concentration $(84 \pm 0.7)$ followed by ethanol extract $(71 \pm 0.4)$ and aqueous extracts $(70 \pm 0.6)$, with IC 50 value of $170.08 \mu \mathrm{g} / \mathrm{ml}$, $265.71 \mu \mathrm{g} / \mathrm{ml}$ and $279.79 \mu \mathrm{g} / \mathrm{ml}$ respectively. The DPPH activity of standard ascorbic acid showed maximum percent inhibition of $(91 \pm 0.8)$ at $500 \mu \mathrm{g}$ concentration with $\mathrm{IC}_{50}$ value of $105.08 \mu \mathrm{g} / \mathrm{ml}$ (fig. 7)

In our present findings, among the three extracts, the methanol root extract showed maximum antioxidant activity. Plant extracts are widely used as a natural antioxidant because of the presence of polyphenols [30]. Compounds with reducing power indicated that they are electron donors and can reduce the oxidised intermediates of lipid peroxidation process. The reduction of potassium ferricyanide by the various extracts of $C$. junghuhniana root showed their hydrogen donating ability.

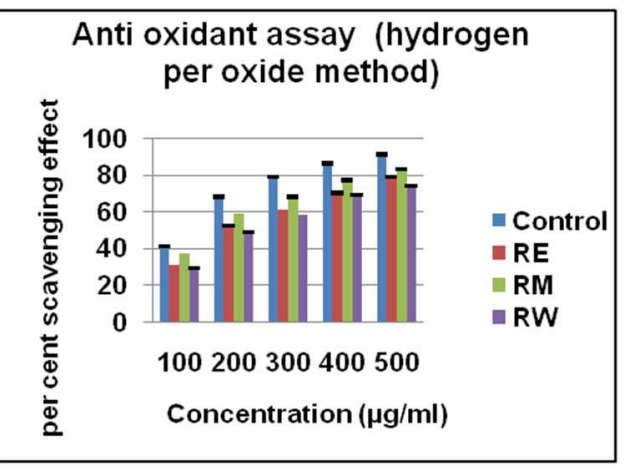

Fig. 5: Hydrogen peroxide scavenging activity of $C$. junghuhniana root. Data presented are the means of three replicates. Values are expressed as mean \pm SD of three replicates

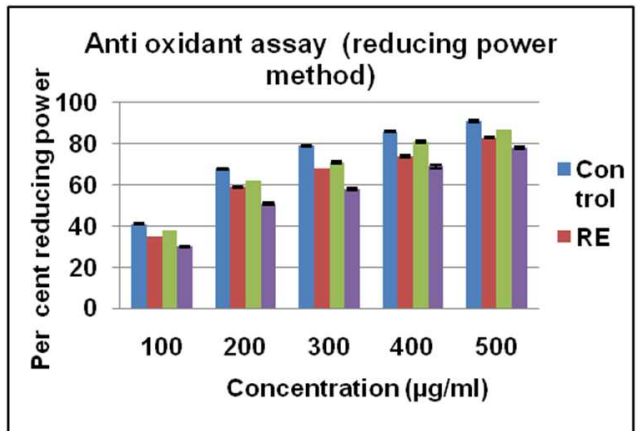

Fig. 6: Reducing power activity of $C$. junghuhniana root. Data presented are the means of three replicates. Values are expressed as mean $\pm S D$ of three replicates

The antioxidant activity of a phenolic compound is mainly due to the redox properties, which play an important role in adsorbing and neutralising free radical, quenching singlet and triplet oxygen, or decomposing peroxides [31]. Plant polyphenols are produced either from phenylalanine or its precursor shikmic acid, are important dietary antioxidants because they possesses an ideal structural chemistry for free radical scavenging activity. Phenolic compounds showed higher antioxidant activity than antioxidant vitamins and carotenoids [32]. Thus, the antioxidant activity of Casuarina junghuhniana may be attributed to the presence of polyphenols in the extracts.

Similar observations were reported in Casuarina equisetifolia using condensed tannins extract from the fine root sample showing the IC50 value of $89.32 \mu \mathrm{g} / \mathrm{ml}$ [33].

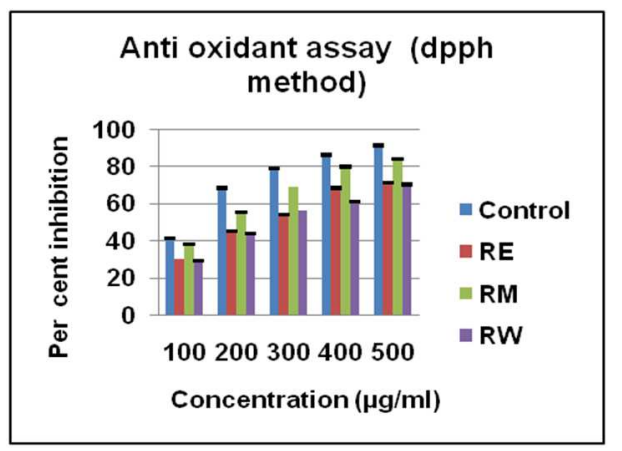

Fig. 7: DPPH free radical scavenging activity of $C$. junghuhniana root. Data presented are the means of three replicates. Values are expressed as mean $\pm S D$ of three replicates

\section{In vitro Anti-inflammatory assay (Inhibition of the albumin denaturation)}

The anti-inflammatory assay was carried out at different concentrations $(100,200,300,400,500 \mu \mathrm{g})$ of Casuarina junghuhniana root extracts. Results revealed inhibition of thermallyinduced protein (albumin) denaturation in a dose-dependent manner. The methanol extract showed maximum percent inhibition $(85 \pm 0.5)$ when compared to ethanol extract $(62 \pm 0.4)$ and aqueous extract $(60 \pm 0.2)$ with IC 50 value of $228.57 \mu \mathrm{g} / \mathrm{ml}, 367.27 \mu \mathrm{g} / \mathrm{ml}$ and $404.34 \mu \mathrm{g} / \mathrm{ml}$ respectively. The anti-inflammatory activity of standard diclofenac sodium showed per cent maximum inhibition $90 \pm 1.5$ at $500 \mu \mathrm{g}$ concentration with $\mathrm{IC}_{50}$ value of $181.11 \mu \mathrm{g} / \mathrm{ml}$. (fig. 8).

Harmful stimuli, pathogens, irritants characterised by redness warmth, swelling and pain are the causes of inflammation of vascular tissue which is a complex biological process. The prolonged inflammation leads to various diseases such as rheumatoid arthritis, atherosclerosis, hay fever, ischemic heart disease [34]. The cause of inflammation is due to protein denaturation which has been well documented [35]. Agents that can prevent protein denaturation, therefore, would be worthwhile for anti-inflammatory drug development. Protein denaturation is a process in which proteins lose their tertiary structure and secondary structure by application of external stress or compound, such as strong acid or base, a concentrated inorganic salt and organic solvent or heat. Most biological proteins lose their biological function when denatured [10]. In the present study, methanol extract showed maximum antiinflammatory activity. The presence of polyphenols and flavonoids in the extracts may be responsible for the anti-inflammatory activity.

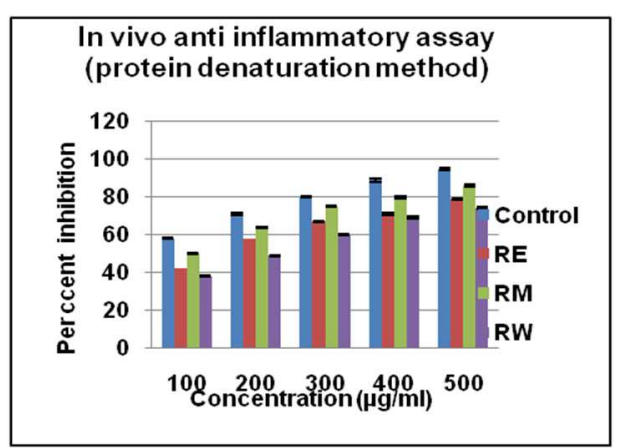

Fig. 8: Anti-inflammatory activity of $C$. junghuhniana root. Data presented are the means of three replicates. Values are expressed as mean $\pm S D$ of three replicates 


\section{GC-MS study}

In the present study, methanolic root extract showed maximum bioactivities; hence GC-MS analysis was carried out only in methanol root extract.

Several peaks were obtained in the GC-MS analysis of methanol extract of $C$. junghuhniana root indicating the presence of different secondary metabolites (fig. 9). These bioactive compounds were identified using NIST database on comparison with actual mass spectral obtained.

The chromatogram revealed the presence of Phenol 3,5 bis $(1,1$ dimethyl ethyl), 4,5,7-trihydroxy isoflavone, 4H-1-Benzopyran 4-one 2-(3,4-dimethoxy phenyl)7-hydroxy, Oleic acid, Ethanol 2 (9 octadecenyloxy) z, Palmitic acid, 3a,9 dimethyl dodecahydrocyclo hepta(d) inden-3-one, Phytol, 4methoxy 5,7 dihydroxyisoflavone, flavone. Among the compounds identified, phenol 3,5 bis $(1,1$ dimethyl ethyl), 4,5,7-Trihydroxy isoflavone, phytol, 4methoxy 5,7 dihydroxyflavone, flavone belongs to phenolic and flavonoid group which possess antibacterial, anti-inflammatory and antioxidant activities [36].

GC-MS is one of the technique to identify the bioactive constituents of long chain branched chain hydrocarbons, alcohols, acids, esters, etc [37]. The results pertaining to GC-MS analysis led to the identification of a number of compounds from the GC fraction of the methanol extract of $C$. junghuhniana root. These compounds were identified through mass spectrometry attached with GC. Most of the compounds in the GC-MS spectrum are grouped under phenolic group. This revels that $C$. junghuhniana is a rich source of phenolic compounds. Phenolic compounds are most widely occurring groups of phytochemicals and derivatives of the pentose phosphate, shikimate and phenylpropanoid pathway in plants. These compounds are secondary metabolites which have an important role in reproduction, growth, protection against pest and pathogens.

The present study strongly supports the presence of therapeutic values such as anti-microbial, anti-oxidant, anti-inflammatory activities which may be due to the presence of a wider range of phenolic phytoconstituents reported [38].

Phytol is one among the identified phytochemicals in the GC-MS analysis. Phytol was observed to have antibacterial activities against Staphylococcus aureus by causing damage to cell membranes. As a result, there is a leakage of potassium ions from bacterial cells [39]. Phytol is a key acyclic diterpene alcohol that is a precursor for Vitamins E and K1. Vitamin E is the main lipid, a soluble antioxidant in the body [40].

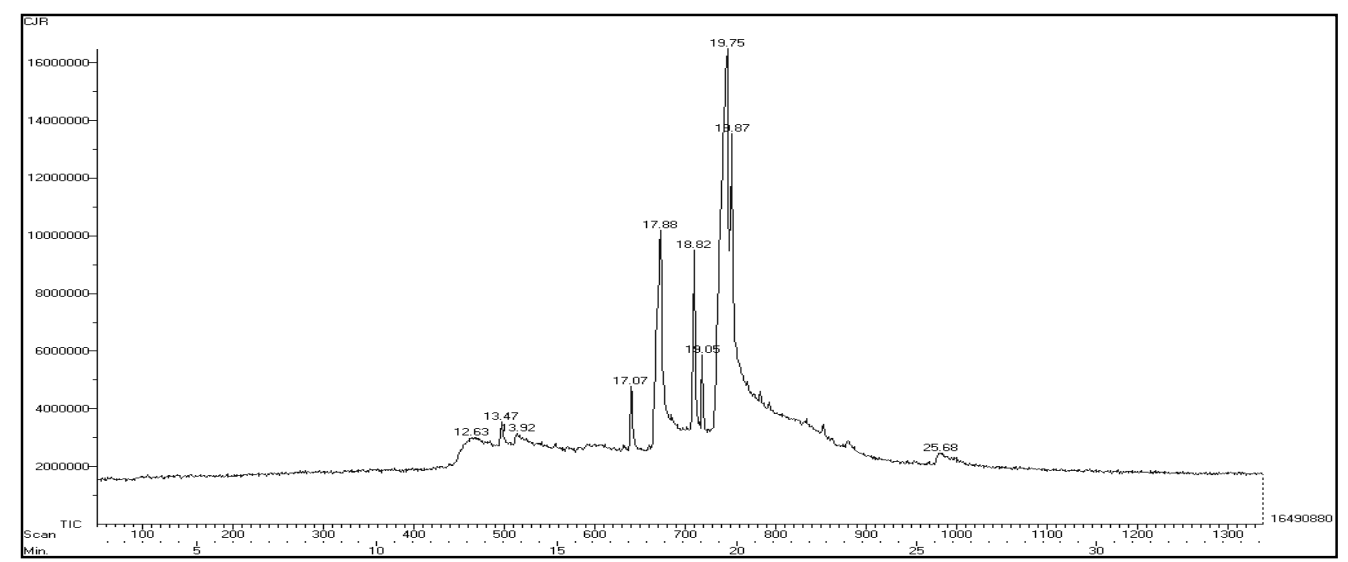

Fig. 9: GC-MS spectrum of $C$. junghuhniana root

\section{Docking studies}

The qualitative and quantitative phytochemical analysis revealed the presence of potent phytochemicals in the root extracts of Casuarina junghuhniana. Further, GC-MS studies confirmed the presence of various phytoconstituents. Thus, from the GC-MS analysis, screening was carried out for the therapeutic compounds related to the antimicrobial property.

Docking studies were carried out to confirm the functional role of the bioactive compound Among the compounds screened, 4 methoxy 5,7 dihydroxyisoflavone from root extract was found to be related to the present study having anti-microbial activity is found to be grouped under flavonoids. Flavonoids are reported to have various biological activities such as antibacterial, antiviral and effective antioxidant potential.

The bioactive compound docked against the target protein Sortase using bioinformatics tool showed the anti-microbial property of the compound through docking scores. More negative values are an indication of higher binding affinity which clearly indicates the strong anti-microbial property. Docking analysis of 4 methoxy 5, 7 dihydroxy-isoflavone showed docking scores of-6.5,-6.2,-6.1 and-6.0. Docking analysis of standard Streptomycin showed docking scores of-6.7,-6.6,-6.3 and6.2 (fig. 10 and 11)).

The gram-positive bacterium Staphylococcus aureus colonises the human skin and causes invasive diseases such as skin and soft tissue infections, osteomyelitis, pneumonia, bacteremia, sepsis and endocarditis [41]. Methicillin-resistant S. aureus (MRSA) acquired resistance against many different drugs including $\beta$-lactam, cephalosporin, fluoroquinolone, aminoglycoside, tetracycline, macrolide, trimethoprim-sulfamethoxazole, and vancomycin antibiotics [42].

The infections caused by $S$. aureus and other pathogens can be treated by using small molecules that effectively strip the bacteria of their surface proteins, which frequently function as virulence factors [43]. Staphylococcus aureus and many other gram-positive pathogens use sortase enzymes to anchor surface proteins to their cell walls that play a key role in the infection process by promoting nutrients acquisition from the host, bacterial adhesion and immune evasion [44-47]. Enzyme Sortase involves in the pathogenesis of a variety of bacterial infections, including respiratory tract, bloodstream, skin and tissue infection.

Sortase has been attracted great interest as potential drug targets since decades. The inhibition of Sortase activity results in the separation of $S$. aureus from the host cells and ultimately alleviation of the infection [48].

In the present study, we used the compound from GC-MS analysis to identify their binding affinity by performing molecular docking studies against the target enzyme Sortase. The compound 4 methoxy 5,7 dihydroxyflavone, which is present in the $C$. junghuhniana root showed prominent binding affinity against Sortase enzyme on par with the standard drug compound Streptomycin. Thus, the docking results are clear evidence for Casuarina junghuhniana root extracts 
possessing anti-microbial properties. The effective potential phytoconstituents can be further purified and taken for future studies.

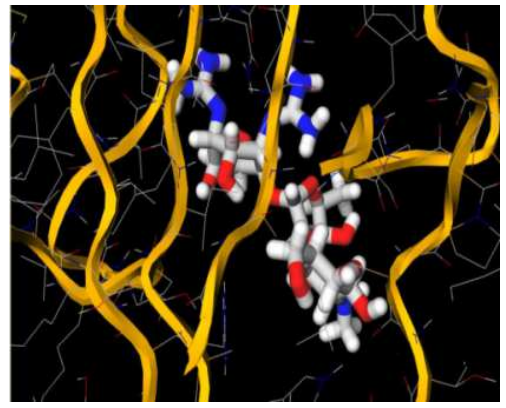

Fig. 10: Illustration of Streptomycin docked against target Sortase

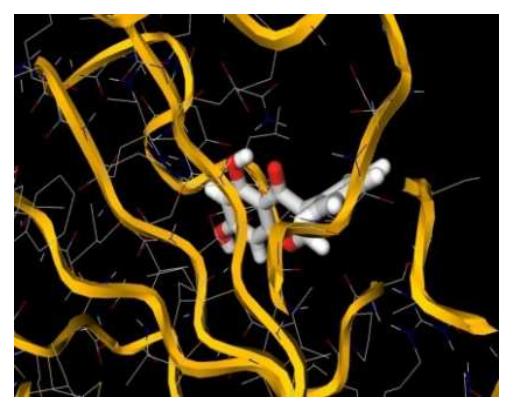

Fig. 11: Illustration of 4 Methoxy 5,7 dihydroxyisoflavone compound from $C$. junghuhniana root (Methanol extract) docked with target Sortase

\section{CONCLUSION}

Casuarina junghuhniana root revealed a broad spectrum of potential phytochemicals, possessing antibacterial, antioxidant and antiinflammatory activities. GC-MS analysis revealed the specific phytoconstituents present in root. Further, docking studies confirmed the compound 4 methoxy 5,7 dihydroxyflavone showing a strong specific antibiotic against the target Sortase. Thus, the study confirms the presence of rich phenol and flavonoid content in Casuarina junghuhniana root extracts. The present work ascertains the potent secondary metabolites of the plant, which could be used in the development of novel drugs. The screened bioactive compounds from the plant will be further purified and studied for its pharmaceutical efficiency and efficacy.

\section{ACKNOWLEDGEMENT}

The authors thank Mrs. Prema Sampathkumar, Associate professor and Head, the Faculty members and non-teaching staff of the Department of Plant Biology and Plant Biotechnology, Dr. Mrs A. Nirmala Principal Ethiraj College for Women, (autonomous) Chennai 600008 , for their valuable support and encouragement throughout the entire period of research. We would also like to express our thanks for the facilities extended by the Central Instrumentation Centre of Ethiraj College for Women. Sincere thanks to State Forest Research Institute, Kolapakkam, Chennai-48 and IIT Madras for extension of facilities.

\section{CONFLICT OF INTERESTS}

Declared none

\section{REFERENCES}

1. Sukanya SL, Sudisha J, Hariprasad P, Niranjana SR, Prakash HS, Fathima $S K$. Antimicrobial activity of leaf extracts of Indian medicinal plants against clinical and phytopathogenic bacteria. Afr J Biotechnol 2009;8:6677-82.
2. Rojas R, Bustamante B, Bauer J, Fernandex I, Alban J, Lock O. Antimicrobial activity of selected peruvian medicinal plants. J Ethnopharmacol 2003;88:199-204.

3. Nicodemus A, Kannan K, Sagariya YC, Vipin P, Durai A, Singh $\mathrm{BG}$, et al. Clonal evaluation of Casuarina junghuhniana for growth and stem form in south India. In: Nicodemus A, Pinyopusarerk K, Zhong CL, Franche C. Editors. Casuarina improvement for securing rural livelihoods. Proceedings of Fifth International Casuarina Workshop; 2016. p. 99-103.

4. Sureshkumar G, Seenivasan R, Chezhian P. Mini-cutting technique for large-scale clonal propagation of Casuarina junghuhniana. In: Nicodemus A, Pinyopusarerk K, Zhong CL, Franche C. Editors. Casuarina improvement for securing rural livelihoods. Proceedings of Fifth International Casuarina Workshop; 2016. p. 118-20.

5. Harborne AJ. Phytochemical methods a guide to modern techniques of plant analysis. 3, Springer Netherlands; 1998. p. 1-8.

6. Raaman N. Phytochmeical Techniques. New India Publishing Agency; 2006. p. 19-25.

7. Samidha Kamtekar, Vrushali Keer, Vijaya Patil. Estimation of phenolic content, antioxidant and alpha-amylase inhibitory activity of marketed polyherbal formulation. J Appl Pharm Sci 2014;4:61-5.

8. Tejavathi DH, Jayashree DR. Phytochemical screening of selected medicinal herbs inoculated with arbuscular mycorrhizal fungi. Int J Biol Pharm Allied Sci 2013:2:2090-106.

9. Ruch RJ, Cheng SJ, Klaunig JE. Prevention of cytotoxicity and inhibition of intracellular communication by antioxidant catechins isolated from Chinese green tea. Carcinogenesis 1989;10:1003-8.

10. Banani Das, Manabendra Dutta Choudhury, Amitabha Dey, Anupam Das Talukdar, Nongalleima KH, Lokesh Deb. Antioxidant and anti-inflammatory activity of aqueous and methanolic extracts of rhizome part of Drynaria Quercifolia (L.) J. Smith. Int J Pharm Pharm Sci 2014;6:43-9.

11. Gopichand Ch V, Anjani A, Himaja A, U Shilpa U, Ravi Kumar A, Chinna Eswaraiah M. Phytochemical evaluation of Lantana camara, Casuarina equisetifolia, Michella nilagirica. Indian J Res Pharm Biotechnol 2015;3:461-3.

12. Hossain MA, Nagooru MR. Biochemical profiling and total flavonoids contents of leaves crude extract of endemic medicinal plant Corydyline terminalis L. Kunth. Pharmacogn J 2011;3:25-30.

13. Mamta Saxena, Jyoti Saxena, Rajeev Nema, Dharmendra Singh, Abhishek Gupta. Phytochemistry of medicinal plants. J Pharmacogn Phytochem 2013;1:168-82.

14. Kokate KC. Practical pharmacognosy. 4th ed. Delhi: Vallabh Prakashan; 1997. p. 218.

15. John Nsor-Atindana, Fang Zhong, Kebitsamang Joseph Mothibe, Mohamed Lamine Bangoura, Camel Lagnika. Quantification of total polyphenolic content and antimicrobial activity of cocoa (Theobroma cacao L.) bean shells. Pakistan J Nutr 2012;11:574-9.

16. Nusrat J Brist, Mohammad F Islam, Sharif M Anisuzzaman, Mohammad N Alam. Antioxidant activity of the water extracts of leaves, root barks, barks of Casuarina littorea. Aust J Basic Appl Sci 2014;8:419-26.

17. Jin Dai, Russell J Mumper. Plant phenolics: extraction, analysis and their antioxidant and anticancer properties. Molecules 2010;15:7313-52.

18. Shahidi F, Wanasundara PKJPD. Phenolic antioxidants. Crit Rev Food Sci Nurt 1992;32:67-103.

19. Rice-Evans CA, Miller NJ, Paganga G. Structure-antioxidant activity relationships of flavonoids and phenolic acids. Free Radical Biol Med 1996;20:933-56.

20. Koda Y. The role of jasmonic acid and related compounds in the regulation of plant development. Int Rtviru Cytol 1992;135:155-99.

21. Leake D, Flavonoids and the oxidation of low-density lipoprotein. Nutrition 2001;17:59-63.

22. Aviram M, Fuhrman B. Polyphenolics flavonoids inhibit macrophage-mediated oxidation of LDL and attenuate atherogenesis. Atherosclerosis 1998;137:S45-S50.

23. Cushnie TPT, Lamb AJ. Antimicrobial activity of flavonoids. Int J Antimicrob Agents 2005;26:343-56. 
24. Chen ZY, Chan PT. Antioxidative activity of green tea catechins in canola oil. Chem Phys Lipids 1996;82:163-71.

25. Bharat Singh, Ram A Sharma. Plant terpenes: defence responses, phylogenetic analysis, regulation and clinical applications. 3 Biotechnology 2015;5:129-51.

26. Cora J Dillard, J Bruce German. Phytochemicals: nutraceuticals and human health. J Sci Food Agric 2000;80:1744-56.

27. Iwu MW, Duncan AR, Okunji CO. New antimicrobials of plant origin. In: Janick J. ed. Perspectives on New Crops and New Uses. Alexandria, VA: ASHS Press; 1999. p. 457-62.

28. Cushnie TPT, Lamb AJ. Antimicrobial activity of flavonoids. Int J Antimicrob Agents 2005;26:343-56.

29. Lal Raisa Helen, Jyothilakshmi M, Latha MS. Phytochemical and antioxidant screening of various extracts of the root bark and leaf of Clerodendrum Infortunatum Linn. Pharmacophore 2014;5:343-51.

30. Nuengchamnong N, Krittasilp K, Ingkaninan K. Rapid screening and identification of antioxidants in aqueous extracts of Houttuynia cordata using LC-ESI-MS coupled with DPPH assay. Food Chem 2009;117:750-6.

31. Osawa T. Novel natural antioxidants for utilisation in food and biological systems. In: I Uritani, VV Garcia, EM Mendoza. Eds. Postharvest biochemistry of plant food materials in the tropics; 1994. p. 241-51.

32. Re R, Pellegrini N, Prosegment A, Pannala A, Yang M, RiceEvans C. Antioxidant activity applying an improved ABTS radical cation decolorization assay. Free Radical Biol Med 1999;26:1231-7.

33. Shang-Ju Zhang, Yi-Ming Lin, Hai-Chao Zhou, Shu-Dong Wei, Guang-Hui Lin, Gong-Fu Ye. Antioxidant tannins from stem bark and the fine root of Casuarina equisetifolia. Molecules 2010;15:5658-70

34. Sherwood ER, Toliver-Kinsky T. Mechanisms of the inflammatory response. Best Pract Res Clin Anaesthesiol 2004;18:385-405.

35. Libby P. Role of inflammation in atherosclerosis associated with rheumatoid arthritis. Am J Med 2008;121:S21-S31.

36. Rajeswari G, Murugan M, Mohan VR. GC-MS analysis of bioactive components of Hugonia mystax L. (Linaceae). Res J Pharm Biol Chem Sci 2012;3:301-8.
37. Sathiyabalan G, Packia Lincy M, Muthukumarasamy S, Mohan VR. GC-MS analysis of bioactive components of Petiveria alliacea L. whole plant (Phytolaccaceae). Int J Pharma Res Health Sci 2014;2:387-92.

38. Venkata Raman B, Samuel LA, Pardha Saradhi M, Narashimha Rao B, Naga Vamsi Krishna A, Sudhakar M, et al. Antibacterial, antioxidant activity and GC-MS analysis of Eupatorium odoratum. Asian J Pharm Clin Res 2012;5:99-106.

39. Inoue Y, Hada TA, Shiraishi K, Hirore, H Hamashima, Kobayashi S. Biphasic effects of geranylgeraniol, terpenone and phytol on the growth of Staphylococcus aureus. Antimicrob Agents Chemother 2005;49:1770-4.

40. Harrera E, Barbas C. Facultad de ciencias experimentales technicas, universidad san pablo CEU, boadilla del monte, madrid, spain. Cherrera@ceu.es. J Physiol Biochem 2001;57:42-56.

41. Lowy FD. Staphylococcus aureus infections. N Engl J Med 1998;339:520-32.

42. Chambers HF, Deleo FR. Waves of resistance: Staphylococcus aureus in the antibiotic era. Nat Rev Microbiol 2009;7:629-41.

43. Maresso AW, Schneewind O. Sortase as a target of anti-infective therapy. Pharmacol Rev 2008;60:128-41.

44. Schneewind O, Missiakas DM. Protein secretion and surface display in Gram-positive bacteria. Philos Trans R Soc London Ser B 2012;367:1123-39.

45. Spirig T, Weiner EM, Clubb RT. Sortase enzymes in Grampositive bacteria. Mol Microbiol 2011;82:1044-59.

46. Clancy KW, Melvin JA, McCafferty DG. Sortase transpeptidases: insights into the mechanism, substrate specificity, and inhibition. Biopolymers 2010;94:385-96.

47. Marraffini LA, Dedent AC, Schneewind O. Sortases and the art of anchoring proteins to the envelopes of gram-positive bacteria. Microbiol Mol Biol Rev 2006;70:192-221.

48. Yahia Nasser Mabkhot, Munirah S Al-Har, Assem Barakat, Fahad D Aldawsari, Ali Aldalbahi, Zaheer Ul-Haq. Synthesis, antimicrobial and molecular docking studies of quinazolin4(3H)-one derivatives. Molecules 2014;19:8725-39.

\section{How to cite this article}

- Chathurdevi G, S Umagowrie. Potent bioactive metabolites of casuarina junghuhniana miq. roots-a therapeutic approach. Int J Pharm Pharm Sci 2017;9(3):158-165. 